\title{
Education in primary school as a strategy to control dengue
}

\author{
Educação de escolares de primeiro grau como \\ estratégia no controle do dengue
}

\author{
Newton G. Madeira1', Carlos Alberto Macharelli², José Figueiredo Pedras ${ }^{3}$ \\ and Maria C.N. Delfino'
}

\begin{abstract}
The proliferation of Aedes aegypti, a species of mosquito that is the vector of the dengue pathogen, is being augmented by the population's lack of care in allowing the formation of larval habitats. One form of controlling dengue is the distribution of information on the mosquito to improve awareness and to provide the means necessary for the elimination of its reproductive habitats. To evaluate a teaching method concerning the vector and dengue, students from the $5^{\text {th }}$ and $6^{\text {th }}$ years of primary education were compared before and after didactic intervention with a group of control students. The students who received intervention were more successful in identifying the stages of the cycle, biological and morphological characteristics of the adult insect and the importance of the mosquito in health issues. The didactic intervention was successful in developing knowledge leading to increased awareness of the importance of preventative measures that should be taken against the vector and the disease.
\end{abstract}

Key-words: Dengue. Aedes aegypti. Education. Community participation.

Resumo A proliferação do Aedes aegypti é propiciada pelo habito de permitir a formação de criadouros em vários tipos de recipientes. Uma das formas de controla-lo é a disseminação do conhecimento sobre o vetor, por conduzir a conscientização e a tomada de medidas contra a sua proliferação. Para avaliar um método de ensino sobre 0 vetor e a dengue, foram comparando alunos de $5^{\underline{a}}$ e $6^{\underline{a}}$ séries antes e após a intervenção didática. Os alunos com intervenção foram mais aptos em reconhecerem as fases do ciclo e tiveram um discernimento maior sobre a importância dos mosquitos para a saúde. Eles também foram mais aptos em reconhecerem quais medidas de controle são mais eficientes e viáveis, repercutindo em suas residências que apresentaram duas vezes menos criadouros em relação aos que não tiveram intervenção.

Palavras-chaves: Dengue. Aedes aegypti. Educação. Participação comunitária.

In Brazil, the yellow fever mosquito Aedes aegypti which is also the vector for dengue, was detected in 2714 municipal regions in the $1997^{12}$, and presents an association with the human environment. Outside of this environment, the vector is generally not found and when it does occur it is temporary and does not persist. Such that, man is principally responsible for the maintenance of the mosquito in the environment by providing various types of disposable recipients that collect water and may become larval habitats.

Dengue epidemics have occurred in various regions of the Country, from 1982 to $1997,952,040$ cases of dengue were registered. Since there is no treatment or even a vaccine against the disease, control and prevention programs must be implemented to stop the multiplication of the vector, principally in its larval phase, by destroying its habitats and combating the adult insect. Although there have been reports that control of the adult insect causes a small impact on the mosquito population ${ }^{4}$ the ability of insecticide spraying, in ultra low volume quantities using vehicles, to interrupt epidemic outbreaks has not been well-defined ${ }^{10}$.

The vector's cycle may be completed in a short timespan, during the hot months, needing only ten days to complete the cycle from eggs to adults under natural conditions, demonstrating that the action of governmental health bodies alone cannot combat the vector. The participation of the population is essential

\footnotetext{
1. Departamento de Parasitologia do Instituto de Biologia da Universidade Estadual Paulista (UNESP), Botucatu, SP. 2.Departamento de Saúde Pública da Faculdade de Medicina da Universidade Estadual Paulista, Botucatu, SP. 3. Departamento da Botânica da Universidade Estadual Paulista, Botucatu, SP. Address to: Dr. Newton Goulart Madeira. Dept ${ }^{\circ}$ de Parasitologia/IB/UNESP. Caixa Postal 510, 18618-000 Botucatu, SP

Tel: $55146821-2121$, Fax: $55146821-3744$

e-mail: nmadeira@ibb.unesp.br

Recebido para publicação em 10/11/2000.
} 
for control in order to prevent the systematic replacement of containers that collect water and which were eliminated by the control teams ${ }^{1}$. Education of school pupils was the factor which triggered the engagement of the community in the control of the mosquito transmitter of filarial parasites ${ }^{9}$. Likewise, the participation of the local population helped to end the transmission of Chagas' disease $^{3}$. Education constitutes an effective manner to modify behavior in relation to the formation of larval habitats for the dengue mosquito ${ }^{7}$ and, in the school environment, has a long duration and should form part of a strategy to include the community ${ }^{5}$.

The school environment is excellent for the development of an educational module on dengue, principally because of its division by age and level of knowledge, allowing teaching to be conducted at different levels of complexity. The presence of the teacher together with pupils throughout the year favors the maintenance of initial sensitization with the aim of inducing participation in the reduction of larval habitats in their homes, since punctual information alone is not sufficient for changing behavior.

The capacity of individuals to recognize and know how to deal with the different types of containers which may serve as larval habitats and prevent this occurring is an initial factor in the understanding that larval habitats should not be allowed to form either at home or anywhere in the city.

In this paper, an educational program is proposed for students regularly attending primary schools on the biology of the vector and its relation to the pathogen, with dengue as the model. The program is quantitatively and qualitatively analyzed.

\section{MATERIAL AND METHODS}

The study was developed with eight groups of students from the $5^{\text {th }}$ and $6^{\text {th }}$ elementary teaching years of the state school "Escola Estadual de $1^{\circ} \mathrm{e}$ $2^{\circ}$ Graus Prof. Euclides de Carvalho Campos" in the city of Botucatu, São Paulo (Brazil). The science teachers of these years were contacted and the objective and form of the project explained and their collaboration was requested. The study was initiated following acceptance by the teachers and directors of the school.

A homogenization of the didactic intervention was one of the key issues, in our opinion, and for this reason only one teacher was trained to give the dengue module and was responsible for the development of the didactic program. The sample size was 314 students which were divided into two groups, the first group $(N=142)$, received didactic activities on dengue and the second group $(\mathrm{N}=172)$ did not, and functioned as a control group. To avoid interference in the results arising from an exchange of information, the first group was composed of classes which attended school in the morning and the second in the afternoon. The division respected the same degree of education between the two samples.

The evaluation of preliminary knowledge, between the two groups on the proposed subject, was obtained by way of a questionnaire containing 14 multiple-choice questions. The questionnaire was given to all the students, who had 20 minutes to individually answer them, after this time they were collected and analyzed. The questions were distributed into topics on the life cycle of the vector, the mechanism of transmission of the virus, habitats, measures to control vectors and symptoms and prevention of the disease.

Teaching centered on activities and discussions regarding manners in which the students could take part in control measures against dengue. The didactic activities were carried out in four fifty-minute lessons, distributed over two consecutive weeks. In the first lesson, after completing the questionnaire, there was an explanation on the biology of the insect in all its stages of development and the morphology that the insect presents in each one of these. Information on the disease, causal agent, transmission and prevention was also presented. The pathology and symptoms were given in an extremely succinct form, so that the students could understand that the illness can be serious and to underscore its consequences. In the second lesson, the 23-minute film "Dengue, join the fight" was shown, after the film a debate was organized, questions raised and an exercise book was distributed. In the third lesson, the complete life cycle of the mosquito from egg to adult was shown, these were also observed under a stereoscopic microscope. The rest of the lesson was reserved for activities proposed in the exercise book. The second questionnaire was given in the forth lesson. This questionnaire maintained the same structure as the first, varying the form of questions, since instead of the multiple-choice questions of the first questionnaire, the questions were open, the time for answering was also increased to 50 minutes. The information obtained was analyzed using the Epi-Info program. The answer data from the two groups were compared by the Chisquared test at a 0.05 level of statistical significance.

\section{RESULTS}

The two groups did not differ significantly in the manner in which their information had been previously obtained, the students answered that on average they had received their knowledge regarding dengue by three forms. The first means of communication most cited was the that of television, followed in descending order by, teachers, relatives, radio, newspaper and physicians, the two groups only differed in the level of information 
learned from newspapers (Table 1). The comparison of the answers from the first questionnaire, obtained before intervention, demonstrated that the majority of students have a lower level of knowledge regarding the locations in which $A$. aegypti reproduce. Regarding the transmission of dengue, the students were relatively well-informed and very well-informed on prevention and how to proceed if infection is suspected (Table 2 ). The two groups differed significantly on five questions, in that the group that did not receive the intervention correctly answered four questions more than the other group, but in other aspects there was no significant difference between the group of students to be studied and the control group (Table 2).

Due to the difference in evaluation methods utilized; the multiple-choice questionnaire in the first evaluation and the open questions in the second, a comparison of students before and after intervention could not be made.

\begin{tabular}{|c|c|c|c|}
\hline & & & Chi-square \\
\hline & Intervention & Control & Significance \\
\hline \multirow[t]{2}{*}{ Television } & 87.3 & 85.5 & 0.097 \\
\hline & & & NS \\
\hline \multirow[t]{2}{*}{ Teacher } & 69.7 & 61.6 & 1.90 \\
\hline & & & NS \\
\hline \multirow[t]{2}{*}{ Relatives } & 52.8 & 57.6 & 0.529 \\
\hline & & & NS \\
\hline \multirow[t]{2}{*}{ Newspaper } & 41.5 & 56.4 & 6.28 \\
\hline & & & $P=0.012$ \\
\hline \multirow[t]{2}{*}{ Radio } & 42.96 & 56.98 & 2.07 \\
\hline & & & NS \\
\hline \multirow[t]{2}{*}{ Physician } & 69.7 & 61.6 & 1.02 \\
\hline & & & NS \\
\hline
\end{tabular}

Table 2 - Comparison between the classes (before didactic intervention) that were to receive lessons and the control group.

\begin{tabular}{|c|c|c|c|}
\hline Question & $\begin{array}{c}\text { Intervention } \\
\% \text { correct }\end{array}$ & $\begin{array}{l}\text { Control } \\
\% \text { correct }\end{array}$ & $\begin{array}{c}\text { Chi-square } \\
\text { and Significance }\end{array}$ \\
\hline \multirow[t]{2}{*}{ At what time of the year are there more mosquitoes? } & 48.2 & 56.1 & 77.4 \\
\hline & & & $P=0.0001$ \\
\hline \multirow[t]{2}{*}{ Which diseases are transmitted by mosquitoes? } & 80.92 & 93.02 & 23.4 \\
\hline & & & $P=0.001$ \\
\hline \multirow[t]{2}{*}{ How can you catch dengue? } & 79.65 & 70.47 & 53.3 \\
\hline & & & $P=0.001$ \\
\hline \multirow[t]{2}{*}{ Do all mosquitoes transmit dengue? } & 68.3 & 69.2 & 0.005 \\
\hline & & & NS \\
\hline \multirow[t]{2}{*}{ Which places can become breeding places for $A$. aegypti? } & 62.5 & 79.37 & 4.53 \\
\hline & & & $P=0.033$ \\
\hline \multirow[t]{2}{*}{ In your home is there any place where $A$. aegypti can breed? } & 23.6 & 24.9 & 0.012 \\
\hline & & & NS \\
\hline \multirow[t]{2}{*}{ Which places are breeding habitats for the dengue mosquito? } & 2.72 & 10.3 & 5.86 \\
\hline & & & $P=0.015$ \\
\hline \multirow[t]{2}{*}{ The mosquitoes may reproduce in which places? } & 41.4 & 35.1 & 0.938 \\
\hline & & & NS \\
\hline \multirow[t]{2}{*}{ What is the best way to eliminate $A$. aegypti ? } & 80.67 & 87.86 & 0.434 \\
\hline & & & NS \\
\hline \multirow[t]{2}{*}{ What are the symptoms of dengue? } & 73.0 & 88.8 & 0.125 \\
\hline & & & NS \\
\hline \multirow[t]{2}{*}{ What should you do when a person has dengue? } & 96.4 & 98.2 & 1.50 \\
\hline & & & NS \\
\hline What can you do to prevent dengue? & 95.7 & 92.2 & 1.80 \\
\hline
\end{tabular}


The analysis following didactic intervention demonstrated a significant difference in the level of correct answers between the two groups. The first item analyzed, the life cycle, was known much better by the students submitted to intervention (44.4\%) than by the control students $(1 \%, p<0.0001)$. The same occurred in relation to the recognition of the morphology of the adult $A$. aegypti, $33.4 \%$ of the didactic intervention group correctly identified the characteristics of this phase in comparison to only $8.1 \%$ of the control group $(p<0.0001)$. The evaluation of the transmission item demonstrated that the didactic intervention students were better able $(73.8 \%)$ to evaluate the importance and the role of the adult in the transmission of dengue than the control group $(25.5 \%)(p<0.0001)$. A greater number of students that did not receive lessons $(43.9 \%)$ reported the presence of larval habitats in their homes than the students that received intervention $(23 \%, p=0.0015)$, although when a definition of a larval habitats was asked for, just $72.3 \%$ of the trained students answered correctly compared to $80.6 \%$ of the control group, a difference that was not statistically significant $(p=0.194)$. The perception of what is necessary for the formation of a larval habitat was not well understood by the students since just, approximately, $26 \%$ of both groups managed to answer correctly. Both groups, though, were able to number the existing larval habitats in their houses, such as, vases with aquatic plants, bottles, cans, tires, outside plastic containers, etc. The symptoms of classical dengue were better known $(74.6 \%)$ by the students that received lessons, differing significantly $(p<0.0001)$ from those that did not, $41.8 \%$ of whom answered the question correctly. The same occurred in relation to the symptoms of hemorrhagic dengue fever; $27.8 \%$ of the intervention students knew what the symptoms were compared to $5.1 \%$ of the control group ( $p<0.0001)$.

Some type of control measure to prevent the dengue mosquito was being undertaken by $100 \%$ of the students that received the lessons and by $98.8 \%$ of those that did not $(P=0.962)$. The families of the students that take control measures were in the same proportions (84.9 and $81.6 \%$ ) and did not differ between the groups, $(p=0.634)$, there was also no significant difference $(p=0.442)$ between the neighbors of the two groups (24.7 and 19.4\%). When the students were questioned as to which other control measures may be taken that were not previously mentioned, $11.9 \%$ of intervention students were able to suggest correct new measures, against not one of the control students, this difference between the groups was significant $(p<0.0001)$. When they were asked which control measures should be utilized in the community environment, the level of correct answers was $84 \%$ in the intervention group and $92.9 \%$ in the control group $(p=0.0011)$. In the group that did not receive intervention, $10.7 \%$ of students listed control measures that were not applicable, such as, Whenever I feel something I go to the doctor for treatment or Because I cannot do anything.

The visiting of 66 residences of the participating students demonstrated that $90.9 \%$ of them live in ground-level houses. The majority of houses receive water from the public system (92.3\%), $4.6 \%$ take water from wells and the rest $(2.8 \%)$ did not specify their source of water, although $96.5 \%$ store water in a water tank. Larval habitats existed in $46 \%$ of the residences, of these, $8.6 \%$ contained water tanks indicated as being larval habitats, but the most frequent larval habitats found were aquatic plant vases $(53.2 \%)$ and plates placed under flower pots containing soil $(27.7 \%)$. Other sites mentioned were tanks (4.3\%) and disposable objects $(2.1 \%)$. Waste is largely collected by the municipal service $(86.4 \%)$, some bury it $(6.1 \%)$ or burn it $(3 \%)$, only $1.5 \%$ is recycled and $3 \%$ admitted that their waste is left on vacant sites. All of the residents stated that they had received information on dengue, $100 \%$ mentioned the television, $83.9 \%$ the radio, $57.1 \%$ leaflets, $59 \%$ newspapers and $50 \%$ a health visitor as the principle sources of information. A residential visit by the health agency was reported by $61.9 \%$ of those interviewed and $100 \%$ affirmed that there had been no cases of dengue in their residence.

\section{DISCUSSION}

The comparison between the two types of questionnaire utilized demonstrated that the second questionnaire, while more suited for demonstration of aspects in the didactic intervention, did not achieve its initial objectives, thereby allowing us to see which adjustments should be made in the dengue module. The analysis of the incorrect answers allowed us to verify if they were due to faults in the didactic content of the presentation or due to errors in the design of the questions.

Open questions are more difficult and timeconsuming to mark and tabulate, requiring the marker to possess an in-depth knowledge. Another critical point is the fact that the scoring of these questions is subject to individual variation on the part of the marker, where more or less rigor influences in some form the final result. To avoid this, the same criteria should be adopted by all the markers.

The previous level of knowledge on dengue was very high, principally regarding the transmission and control items, possibly a reflection of the information obtained by the student from various media sources. Although the level of knowledge was demonstrated to be equal between the control and intervention groups for the majority of questions, the intervention students behaved differently after receiving the dengue module, indicating that the initial information was insufficient or was not well-developed. When the female residents of 537 
households (who obtained their information by way of communication media and from leaflets, seminars and/ or posters), the large majority of them possessed a satisfactory level of knowledge regarding dengue, although the number of larval habitats remained high in their residences ${ }^{12}$, demonstrating that this form of education did not achieve the proposed objectives. Our control group, despite initially presenting the same level of knowledge as the intervention group, had a lower level of action and knowledge in relation to the other group after intervention. The lack of action by the population to control the vector may be attributed to this fragmented knowledge. For example, when those responsible for the education of the population inform people that they should not accumulate containers considered as being waste, the people receiving this message interpret it according to their definition of waste and make the decision as to whether it should be discarded or not, thus the concept of what is waste varies within the community $^{8}$. Various objects, considered by the educating team, as disposable are considered useful and stored by the inhabitants. The inhabitants are unaware of the fact that these stored containers may become larval habitats for the mosquito, since they were taught that only disposable containers are larval habitats. It seems that when people are accompanied for some time, the message is better processed and there is some corresponding change in attitude. Some studies performed on populations show that where time is spent in providing the target population with adequate educational material, the results and knowledge favor a change in the behavior of the population resulting in a fall in the number of breeding sites for $A$. aegypti ${ }^{7}$ and the number of Culex quinquefasciatus adults ${ }^{9}$. The opposite occurred when information was distributed among the population using communication media, posters, leaflets and seminars ${ }^{12611}$.
The students have an increased interest in the material content to be taught in the classroom when the theme to be covered appears in the media. In the case of dengue, when the information concerns the existence of infected individuals in a locality or there are a large number of breeding sites found, the students comment on what they have heard in the classroom. Although various studies have demonstrated that informal education does not lead to action being taken against the vector, we observed that the information learned from the means of communication helped the students take more interest in the subject. During these times of information release by the media, the teachers may take the opportunity to reinforce certain concepts, clarify doubts and stimulate students to adopt attitudes to prevent the mosquito. Education for the control of $A$. aegypti should take into consideration the nonexistence of the vector for approximately 30 years after its eradication. During this period there was a large migration of inhabitants from the countryside to the cities and at the same time industry began to produce disposable containers which may act as larval habitats. In addition, the preoccupation with the vector was due only to yellow fever, which is found restricted to the wild form and can be prevented with a vaccine. For the population, dengue is a new entity and its hemorrhagic form is unknown by the majority of the inhabitants of the country. In teaching about prevention of diseases in general, dengue should also be taken into consideration in an attempt to stop epidemics of the hemorrhagic form, since its occurrence does not necessarily lead the population to participate in its control ${ }^{11}{ }^{13}$. The dengue module may be inserted into the science teaching curriculum together with topics on the environment, biology and health. In cases of emergency, this module may be developed just once. In our opinion, methods could be adopted which effectively teach students that dengue is a disease that can be controlled by simple measures.

\section{ACKNOWLEDGEMENTS}

We are grateful to the teachers and students of Escola Estadual Professor Euclides C. Campos, to Dr. R. E. Diniz (Dept ${ }^{\circ}$ Educação IB/UNESP), to Paula Selene Barboza and the Ministry of Health (FUNASA).

\section{REFERENCES}

1. Chiaravalloti-Neto F. The population's knowledge concerning dengue fever, vectors, and control measures in São José do Rio Preto, São Paulo State. Cadernos de Saúde Pública 13: 447-453, 1997.

2. Dégallier N, Vilarinhos PTR, Carvalho MSL, Knox MB, Caetano Jr JC. People's knowledge and practice about dengue, its vectors, and control means in Brasília (DF), Brazil: its relevance with entomological factors. Journal of American Mosquito Control Association 16: 114-123, 2000.

3. Garcia A. Human behavior and Chagas' disease. In: New approaches in American Trypanosomiasis Research. Science Publication No. 318, Pan American Health Organization, Washington, p. 319-322, 1976.

4. Gubler DJ. Aedes aegypti and Aedes albopictus borne disease control in the 1990s: top down or bottom up. American Journal of Tropical Medicine and Hygiene 40: 571-578, 1989.
5. Hernández RJS, Cerna EAF, Montes GAA. Evaluación de un programa educativo sobre dengue y Aedes aegypti focalizado en niños de escuela primaria. Revista Medica Hondureña 63: 12-18, 1995.

6. Lenzi MF, Camillo-Coura L, Grault CE, Val MB. Estudo do dengue em área urbana favelizada do Rio de Janeiro: considerações iniciais. Cadernos de Saúde Pública 16: 851-856, 2000.

7. Lloyd LS, Wich P, Ortega-Canto J, Kendall C. Results of a community-base Aedes aegypti control in Merida,Yucatan, Mexico. American Journal of Tropical Medicine and Hygiene 46: 635-642, 1992.

8. Mazine CAB, Macoris MLG, Andrighetti MTM, Yasumaro S, Silva ME, Nelson MJ, Wich, PJ. Disposable containers as larval habitats for Aedes aegypti in a city with regular refuse collection: a study in Marília, São Paulo State, Brazil. Acta Tropica 62: 1-13,1996. 
9. Regis L, Furtado A F, Oliveira CMF, Bezerra CB, Silva LRF, Araujo J, Maciel A, Silva-Filha MA, Silva SB. Controle integrado do vetor da filariose com participação comunitária em área urbana do Recife, Brasil. Cadernos de Saúde Publica 12: 473-482,1996.

10. Reiter $P$, Gubler DJ. Surveillance and control of urban dengue vetors. In: Gubler DJ, Kuno G (eds) Dengue and dengue hemorrhagic fever, CAB International, Wallingford, UK, p. 425-462, 1997.

11. Rosenbaum J, Nathan MB, Ragoonanansingh R, Rawlins $S$, Gayle C, Chadee DD, Lloyd LS. Community participation in dengue prevention and control: a survey of knowledge, attitudes, and practice in Trinidad and Tobago. American Journal of Tropical Medicine and Hygiene 53: 111-117,1995.

12. Silveira AC. Dengue: aspectos epidemiológicos e de controle. Revista da Sociedade Brasileira de Medicina Tropical 31: 514,1998.

13. Wich P, Lloyd L, Godas M D, Kendall C. Beliefs about the prevention of dengue and other febrile illness in Merida, Mexico. American Journal of Tropical Medicine and Hygiene 94: 377-387, 1991. 